Portland State University

PDXScholar

\title{
Effects of the nerve during the dedifferentiative phase of limb regeneration in the Mexican axolotl, Ambystoma lilexicanum
}

Roberta Gail Wald

Portland State University

Follow this and additional works at: https://pdxscholar.library.pdx.edu/open_access_etds

Part of the Biology Commons

Let us know how access to this document benefits you.

\section{Recommended Citation}

Wald, Roberta Gail, "Effects of the nerve during the dedifferentiative phase of limb regeneration in the Mexican axolotl, Ambystoma lilexicanum" (1974). Dissertations and Theses. Paper 2410.

https://doi.org/10.15760/etd.2407

This Thesis is brought to you for free and open access. It has been accepted for inclusion in Dissertations and Theses by an authorized administrator of PDXScholar. For more information, please contact pdxscholar@pdx.edu. 
AN ABSTRACI OF THE THESIS OF Roberta Gail Wald for the Master of

Science in Biology presented $11 \mathrm{Ju} 1 \mathrm{y} 1974$.

Title: Effects of the Nerve during the Dedifferentiative Phase of

Limb Regeneration in the Mexican AxolotI, Ambystoma mexicanum

APPROVED BY MEMBERS OF THE THESIS COMMITTEE:

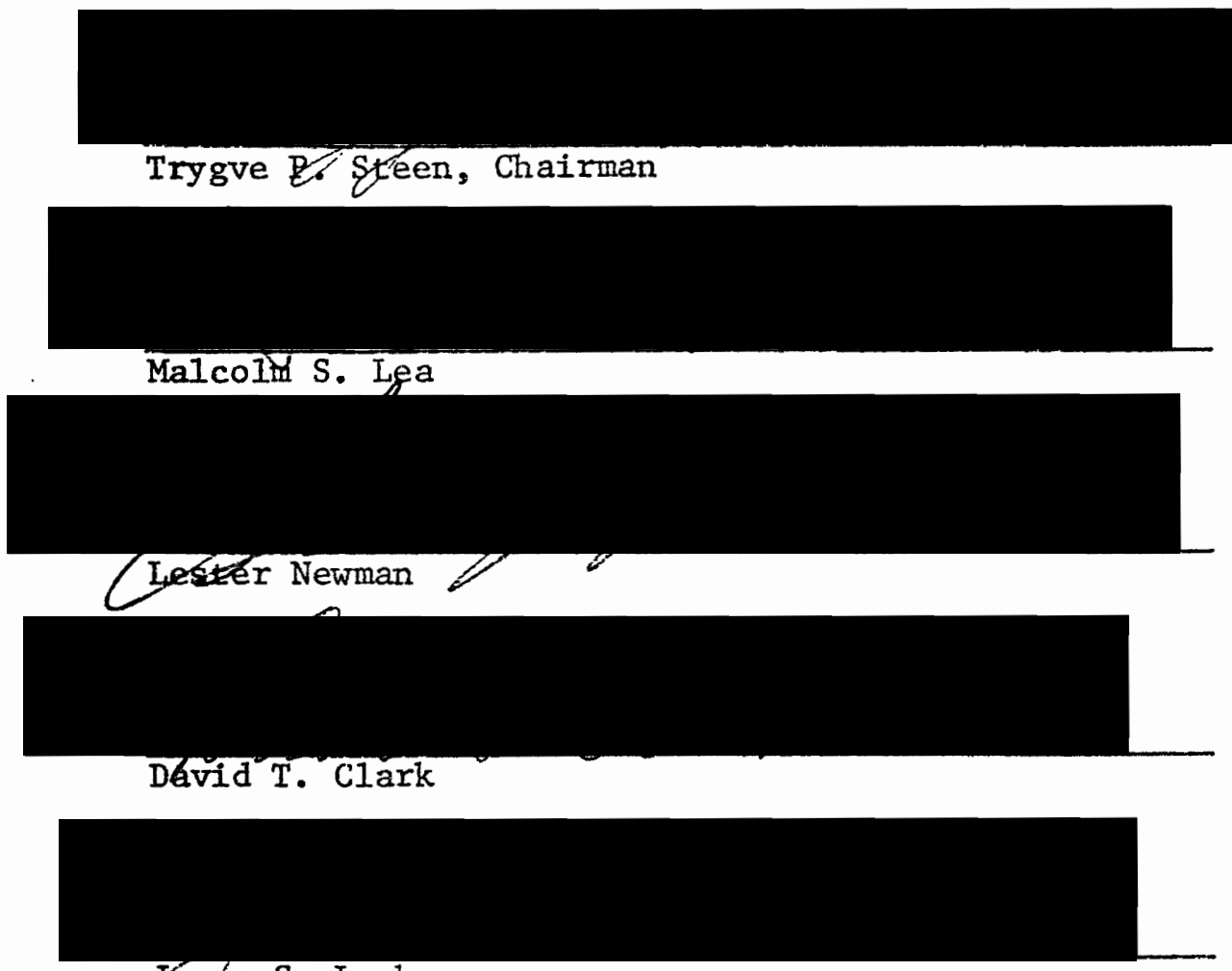

Joañn S. Loehr

It is known that nerves are particularly critical during the early or dedifferentiative phase of limb regeneration. During this period in the innervated limb, cells just proximal to the amputation surface dedifferentiate, migrate to the limb tip, and undergo mitosis. These processes give rise to a population of undifferentiated mesenchymatous cells capable of redifferentiating into the missing components of the newly forming regenerate. The consequences of denervation stand in 
stark contrast to the normal events occurring in the innervated limb, because neither a blastema nor a regenerate forms.

Results from this study indicate that during the early portion of the dedifferentiative phase in regenerates less than $23 / 4$, days old the nerve apparently has little or no effect on the internal stump tissues. of considerable interest in this regard is this study's documentation of a lack of neural influence on DNA synthesis and thus the cell cycle during the early dedifferentiative phase. Subsequently, during a transition period represented by $23 / 4$ to $51 / 2$ days regenerates there is some evidence for a neural influence on DNA synthesis in cells of the limb stump. Finally, on days 6 through 8, DNA synthesis is clearly nerve dependent. Since DNA synthesis is a prerequisite for mitosis, the depressed synthesis in a denervated limb precludes mitotic activity during the nerve-dependent, later portion of the dedifferentiative phase. Therefore, this research supports the idea that during the late dedifferentiative phase, including mound and early cone blastemal stages, there is a neural influence on the $G_{1}$ or $S$ phases of the cell cycle.

This conclusion thereby makes progress toward explaining earlier observations of depressed mitotic activity during this period. 
EFFECTS OF THE NERVE DURING THE DEDIFFERENTIATIVE PHASE OF

LIMB REGENERATION IN THE MEXICAN AXOLOTL, Ambystoma mexicanum

by

ROBERTA GAIL WALD

A thesis submitted in partial fulfillment of the requirements for the degree of

MASTER OF SCIENCE

in

BIOLOGY

Portland State University

1974 
TO THE OFFICE OF GRADUATE STUDIES AND RESEARCH:

The members of the Committee approve the thesis of

Roberta Gail Wald presented 11 July 1974.

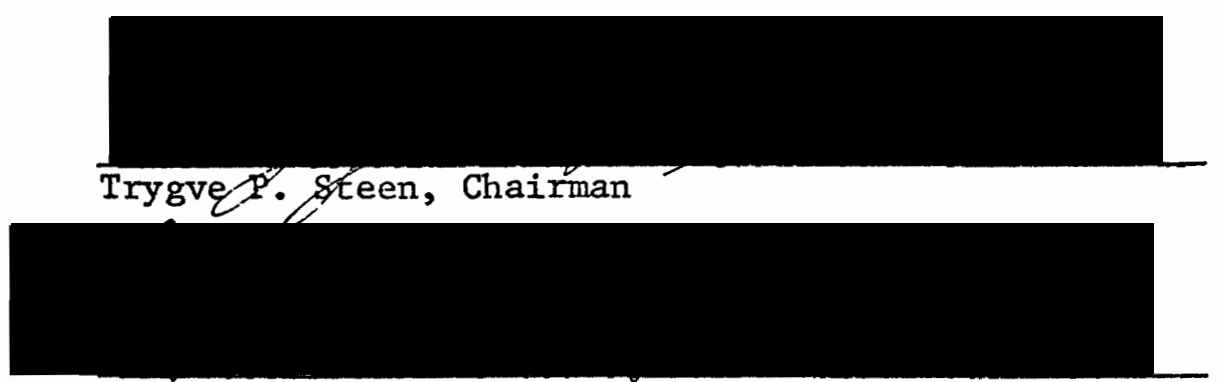

Malcolm S. Lea

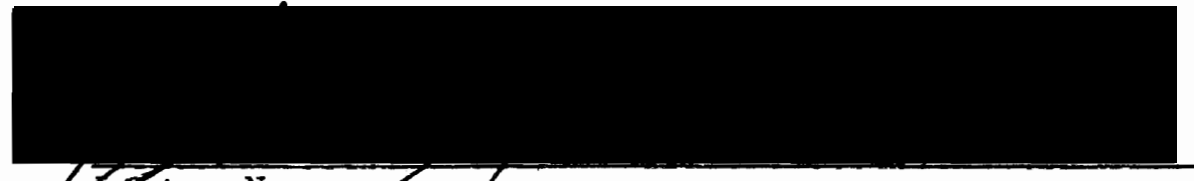

Zester Newman

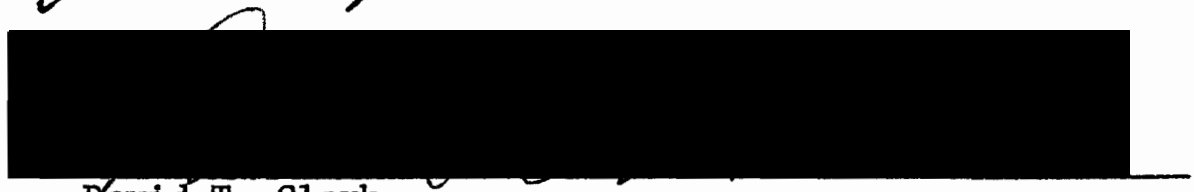

Bavid T. Clark

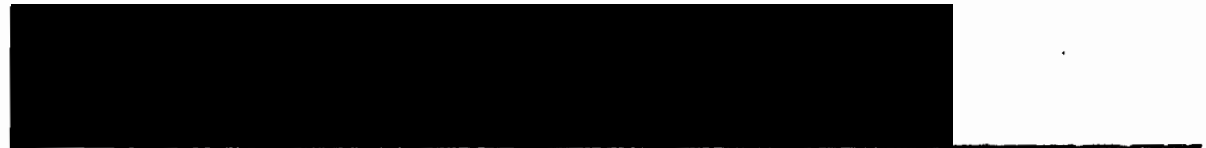

Joann S. Loehr

APPROVED:

EarI Fisher, Jr., Head, Department of Biology

David T. Clark, Dean of Graduate Studies 


\section{ACKNOWLEDGEMENTS}

I wish to express my sincere thanks to Dr. Trygve P. Steen for his invaluable counsel and assistance during the course of this investigation and in the preparation of the manuscript, making this endeavor a valuable educational experience.

Thanks are also extended to Drs. Lester J. Newman, Malcolm S. Lea, Joann Loehr and Dean of Graduate Studies and Research, Dr. David T. Clark for their advice and critical reading of the manuscript and for serving as committee members.

I wish to express my appreciation to the Statistics Department of Oregon State University for their assistance in the statistical analysis.

I. am indebted to my family for the encouragement and understanding that made the completion of this study possible. 
TABLE OF CONTENTS

PAGE

ACKNOWLEDGEMENTS . ............................

LIST OF TABLES $\ldots \ldots \ldots \ldots \ldots \ldots \ldots \ldots \ldots \ldots \ldots \ldots \ldots \ldots \ldots \ldots \ldots \ldots$

LIST OF FIGURES.............................. vi

INTRODUCTION $\ldots \ldots \ldots \ldots \ldots \ldots \ldots \ldots \ldots \ldots \ldots \ldots \ldots \ldots \ldots \ldots \ldots \ldots \ldots$

METHODS AND MATERIALS............................ 4

RESULTS..................................... 12

DISCUSSION. .................................. 26

LITERATURE CITED.............................. 34 


\section{LIST OF TABLES}

TABLE

PAGE

I Sumary of Experimental Parameters.

II Matrix Relating Total Age of Regenerates at the Time of Fixation to Age at Final Injection and Time Interval Between Final Injection and Fixation.............

III Major Experimental Parameters for Each Animal, Including the Mean Percent Labeled Cells in Each Limb and the Probability Values for the Similarity between the Cell Populations of Innervated and Denervated Limbs. 


\section{LIST OF FIGURES}

FIGURE

PAGE

1 Denervated Limb Stained to Show Nerve Fibers............

2 Silver Grains Over Nuclei Indicate Tritiated Thymidine Labeling in the $31 / 2$ Day Regenerate........... 17

3 Normally Innervated Limb Stained to Show Nerves (N)

4 Silver Grains Over Nuclei Indicate the High Level of

Labeling by Tritiated Thymidine in the Innervated

Limb of a Regenerate Late in the Dedifferentiative

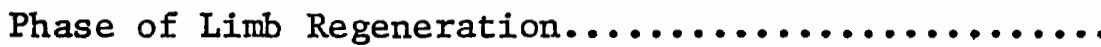

5 Silver Grains Over Nuclei Indicate the Low Level of

Labeling in the Denervated Limb of a Regenerate

Late in the Dedifferentiative Phase of Limb

Regeneration..........................

6 Graphic Illustration of Mitotic Index for Both Innervated and Denervated Limbs During the Dedifferentiative

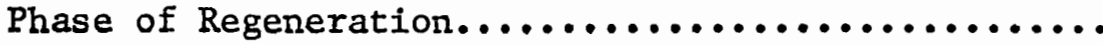

7 Photomicrograph of an 8 1/2 Day Regenerate Illustrates the Accumulation of Cells Beneath the Epidermal Cap (Animal $\|_{19}$ 19.......................

8. Photomicrograph of a Denervated 5 3/4 Day Limb Stump Illustrates the Lack of Blastema Cell Aggregation and the Lack of Epidermal Cap Formation Typical for Denervated Limbs of this Age (Animal \#18)....... 


\section{INTRODUCTION}

Urodele amphibians are capable of limb regeneration, but this capacity is dependent on adequate innervation. Spinal nerves 3,4 and 5 innervate the forelimbs, and if these nerves are severed at the shoulder (denervation) prior to the ninth day of regeneration, regenerative activity slows or stops for as long as nerves are prevented from reinnervatIng the limb (Schotte and Butler, 1941, 1944). The nature of the influence of nerves on developmental aspects of regeneration may vary during different periods of regenerative activity, but there is a definite need for the nerve during the dedifferentiative phase. Furthermore, there appears to be a general influence of the nerve on cell division at a variety of stages (Dresden, 1969; Sperry, 1971; Ke11y and Tassava, 1973).

It is known that nerves are critical for the normal succession of morphological events occurring during the early or dedifferentiative phase of limb regeneration. For the first 24 to 48 hours following limb amputation in the salamander, there is little mitotic activity in the proximal tissues other than in the epidermis, and during this period of time the epidermal cap is forming (Hay and Fischman, 1961). In the following 72 hours (days 2 to 5 ) the internal stump tissues just proximal to the plane of amputation begin to undergo dedifferentiation. Finally, from day 6 to 10 dedifferentiation continues, and the mitotic index rises rapidly (Sperry, 1971; Kelly and Tassava, 1973) as a definite bud of cells, the blastema, is formed at the limb tip. The blastemal cells constitute a population of undifferentiated mesenchymatous cells capable of redifferentiating into the requisite components of the limb regenerate. The events occurring in an amputated, denervated limb, stand in stark 
This study is concerned with the relationship between innervation and cellular aspects of limb regeneration in urodeles. 
METHODS AND MATERIALS

Laboratory reared Ambystoma mexicanum of 50-80 more wsed in this experiment. Animals were maintained in individual finger bowls at $21^{\circ} \mathrm{C}$ $\pm 0.5^{\circ} \mathrm{C}$ in aged tap water which was changed on alternate days. They were fed strips of beef liver for the duration of the experiment, except that no animal was fed for a minimum of 40 hours prior to injection of tritiated thymidine.

One forelimb of each animal was denervated, the contralateral limb serving as the normally innervated control, and both forelimbs were amputated to initiate regeneration. The operations were performed as follows: animals were anesthetized in a 1:3,000 solution of MS222 (Tricalne methanesulfonate, Sandoz); an incision was made through the skin over the scapula at the right shoulder joint using sharpened watchmaker's forceps; spinal nerves 3,4 and 5 to the right limb were resected; and both forelimbs were amputated just proximal to the elbow. All operations were performed at the same time of day in order to standardize diurnal Influences on mitotic events. In order to maintain limbs in a denervated state, it was necessary to perform a second denervation procedure on the fifth day of regeneration for any limb allowed to regenerate six days or more. Sham denervation operations were not performed, since no difference has been found between sham-operated limbs and control limbs with respect to rate of regeneration, DNA synthesis, and mitotic index (Kelly and Tassava, 1973; Dresden, 1969).

The animals were divided into four groups, each group being denervated and amputated a specific number of hours prior to injection of tritlated thymidine (see Table I). All animals were injected on the same day with methyl-3H-thymidine (New England Nuclear, specific activity 6.7 


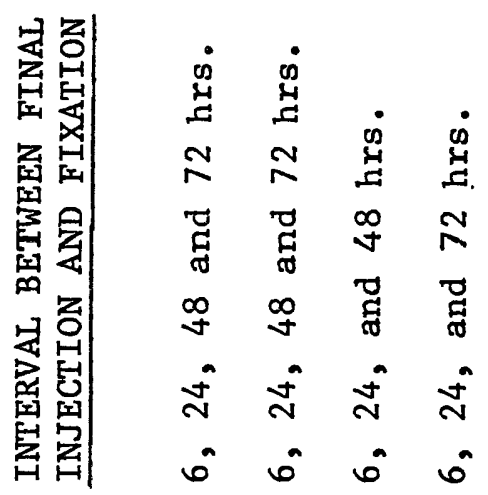
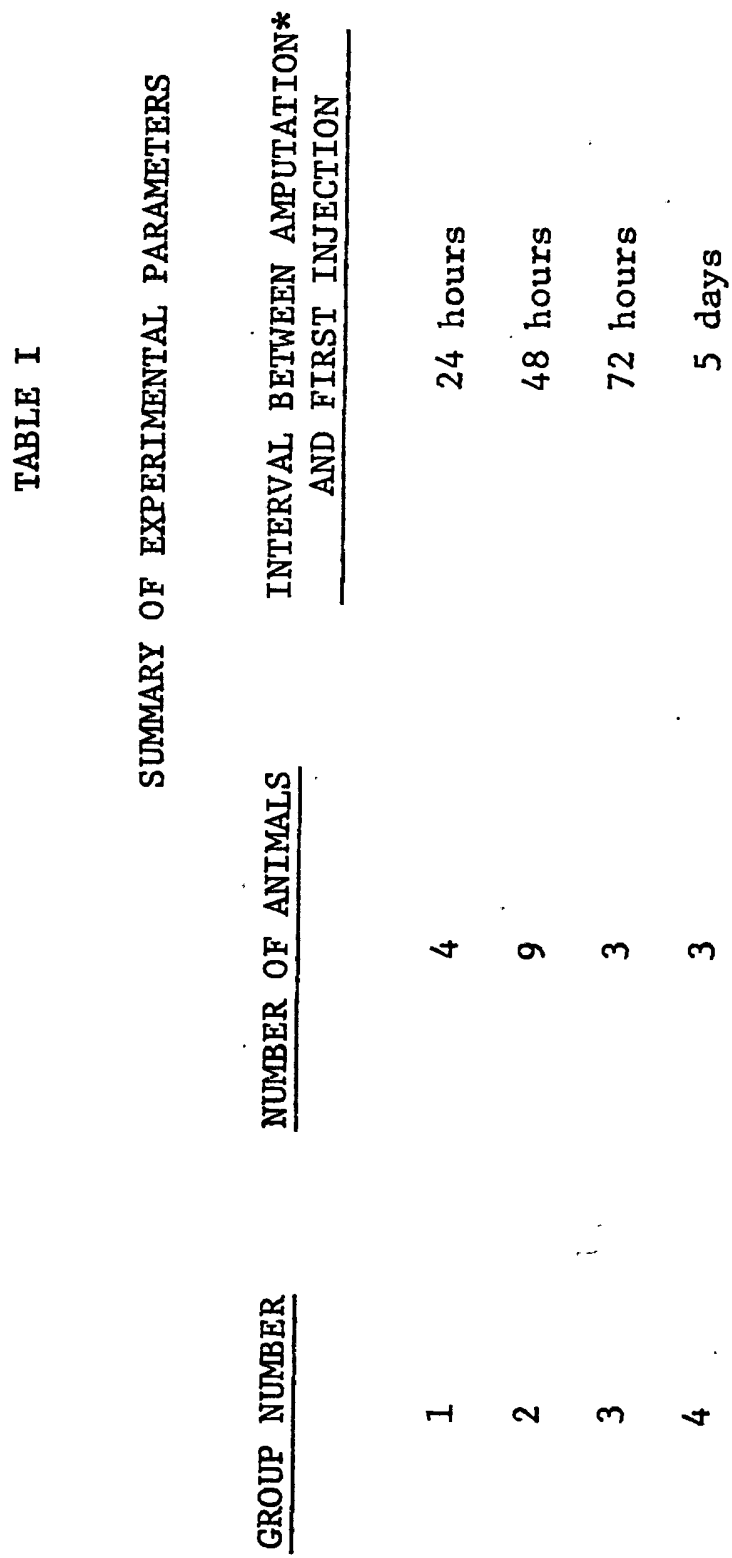
curies per milli mole).

The total dose of tritiated thymidine was $5 \mu \mathrm{c} / \mathrm{gm}$ of body weight, given in three injections of one-third the total dose each, injected intraperitoneally at 6-hour intervals using a 10 Hl Hamilton Syringe. This 6-hour interval was selected because there is a major peak of circulating tritiated thymidine in serum at 1 hour, followed by a rapid decrease in the circulating level of isotope during the next five hours post-injection to a level approximately one-third the amount measured at one hour post-injection (Steen, unpublished). This initial decrease is in sharp contrast to the relatively slow decrease in the circulating level of tritiated thymidine during the ensuing 42 hours. Control experiments using either unlabeled thymidine or distilled water in place of tritiated thymidine were considered unnecessary since it has already been demonstrated that the isotope has no significant effect on regeneration (Steen, 1968).

As the dedifferentiative processes in the limb stump were to be studied, it was necessary not only to inject at several different intervals following denervation and amputation, but also to remove the limb stumps for study at more than one time following injection. Both forelimbs of a given animal were removed and placed in fixative at either 6 , 24, 48 or 72 hours following the third injection (experimental parameters are summarized in Table I and II). Limbs were fixed in Clark's fixative (absolute ethanol-glacial acetic acid, 3:1) for 24 hours, embedded in paraffin, and sectioned longitudinally at $10 \mu$. Sections were affixed to slides with $1 \%$ fresh egg albumin and allowed to dry for two weeks before being run through radioautography. 


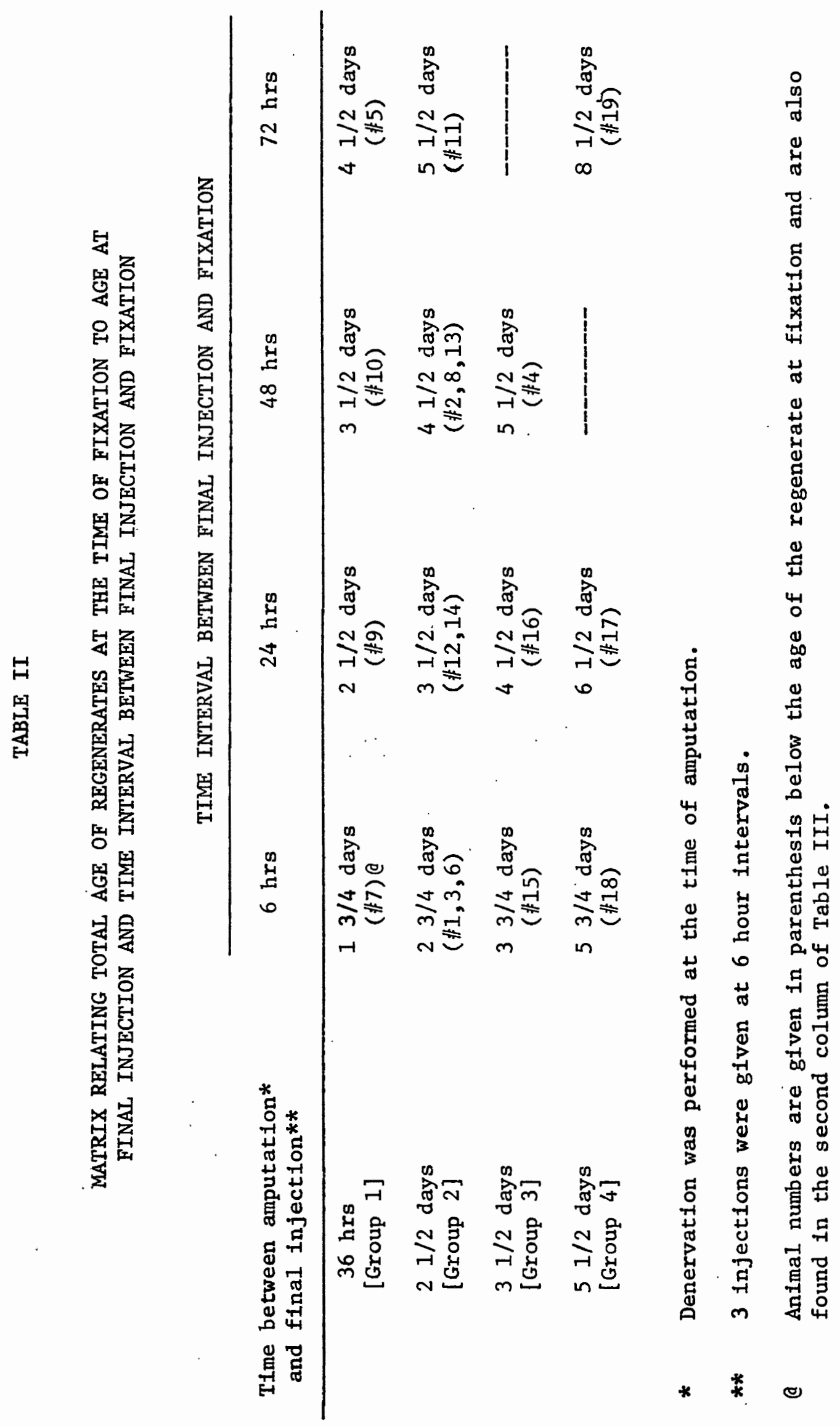


In preparation for radioautography, slides were deparaffinized in two changes of toluene, transferred through two changes of absolute ethano1, placed in absolute ethanol-diethyl ether $1: 1$, then into $100 \%$ diethyl ether, and allowed to air dry. The dried slides were then taken into the darkroom and placed on a warming tray at $40^{\circ} \mathrm{C}$. Illumination was from a safelite with Wratten 非 red filter placed 4 feet above the counter. The slides were dipped for one to two seconds in Kodak NTB-3 at $40^{\circ} \mathrm{C}$, positioned vertically for drying, and placed in a controlled humidity chamber at $28^{\circ} \mathrm{C}$ with a relative humidity of $80 \%$ for 30 minutes. They were then placed in a hydrogen peroxide atmosphere for 5 hours to minimize background silver grains (Caro, 1964) and aired to rid them of the peroxide. Following this treatment, slides were transferred to a lighttight receptacle containing a silica gei-drierite mixture and stored at $4^{\circ} \mathrm{C}$ for 7 days. All slides were developed in Kodak D-19 at $18^{\circ} \mathrm{C}$ for four minutes (agitation 5 seconds of every 30 seconds), followed by a one-minute water rinse, then four minutes in Kodak fixer, a second oneminute water rinse, treated with Permawash for one minute, and finally ten water rinses of one minute each. All slides, except the initial nerve control group, were stained in Azure B according to Flax and Himes (1952).

The presence or absence of nerves in denervated limbs was determined by means of three tests. First, each animal was observed for the ability to move the denervated limb; secondly, the denervated limbs were touched with the sharpened points of watchmaker's forceps to observe any reaction to tactile stimulation. As a third test, randomly selected sections of tissue from the area between the humerus and the epidermis of 
each limb were stained to reveal nervous tissue according to the method of Samuel (1953). However, since nerves are not randomly placed in a limb, and since data from the 2 to 6 day regenerates raised some doubt as to the effectiveness of the denervations, the selected sections were flnally deemed to provide inadequate evidence of denervation. Therefore, all the radioautographs of 32 limbs which had previously been stained using Azure $B$ were restained with nerve stain according to the method of Samuel (1953). With these preparations, it was possible to observe all tissue sections for the presence or absence of nerves. Observations of nuclear DNA synthetic activity as evidenced by the incorporation of tritiated thymidine, consisted of counting all internal tissue cells and simultaneously recording all labelled cells located in the limb tip. The limb tip portion of a given section was defined by measuring $0.5 \mathrm{~mm}$ proximal to the site of amputation and included all cells distal to that line. The area counted in each section contained between 400 and 1,500 cells, depending on the location of the section as well as the age and size of the regenerate. A cell was considered labeled if a minimum of seven silver grains were located over the nucleus. From this data, it was possible to determine the percentage of cells labeled in each tissue section. For most limbs a minimum of elght sections were counted; except for a group of six animals in which four sections were counted from each limb (see Table III).

All mitotic figures occurring in the limb tip area of each tissue section were counted, and each mitotic figure was recorded as either labeled or unlabeled. The tendency for the silve grains to obscure the nuclear area and the difficulty with which early prophase and late 


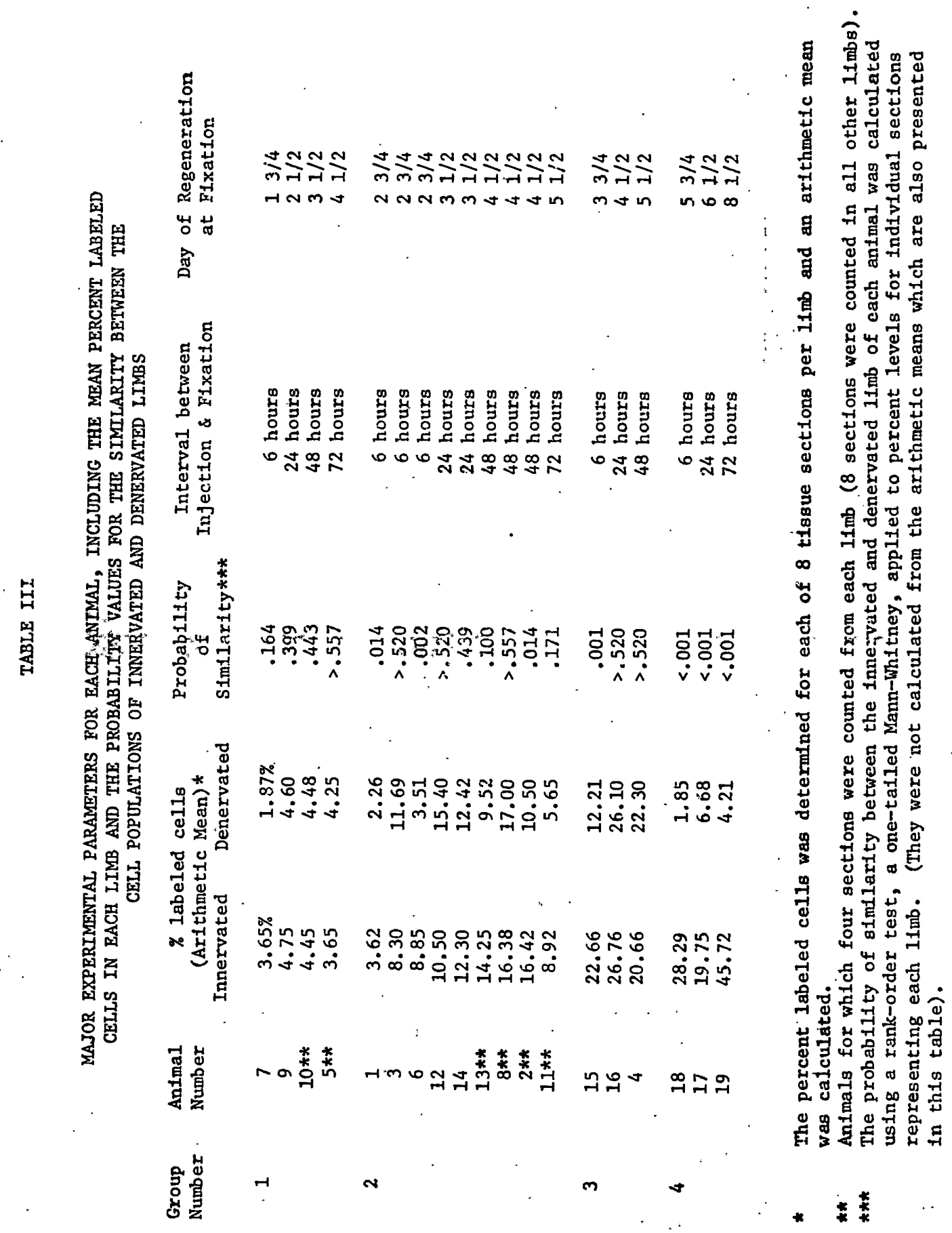


telophase figures are identified necessitated the inclusion of these cells among those counted as interphasic cells. Cells in telophase were counted as one mitotic figure. The mitotic index was caleulated by dividing the total number of cells counted in a given limb into the total number of mitotic figures occurring and multiplying that number by 1,000 (Hearson, 1966). 
RESULTS

The operations to denervate limbs were successful as judged by: a loss of directed movement; a lack of sensitivity to tactile stimulation; and an appropriately low number of nerve fibers in the nerve stained tissue sections. The survey of all sections in each denervated limb is of particular interest. It revealed that the limbs were nerveless or contained only a small quantity of nerve fibers, the majority of which were within degenerating nerves (Figure 1). The denervated limbs used in this study are therefore clearly free enough of nerves to block regeneration, since at least $1 / 3$ of the total nerve supply must remain to permit regeneration (Singer, 1952).

A Iinear regression analysis was performed in order to test the null hypothesis that the mean percent labeled cells (from 8 tissue sections per limb) were similar in both innervated and denervated limbs. Since it was expected that denervation would decrease the percent labeled cells in the denervated limb, a one-tailed test was utilized for $t_{18}^{05} \mathrm{~d} . \mathrm{f}$. and under these conditions the null hypothesis was rejected. It was further determined that $62.7 \%$ of the variation in the mean of the labeled cells in the control (innervated) limb is attributable to time $\left(R^{2}=.627\right)$ whereas in the denervated limb only $0.36 \%$ of the variability is due to increased labeling with time $\left(\mathrm{R}^{2}=.00363\right.$ ) (see Figure 1 ). It should be noted that part of the increase in the percent labeled cells would be due to the increase in the time interval between injection and fixation.

In our analysis of the relationship between time and labeling, two different grouping of animals need to be considered. Our experimental 


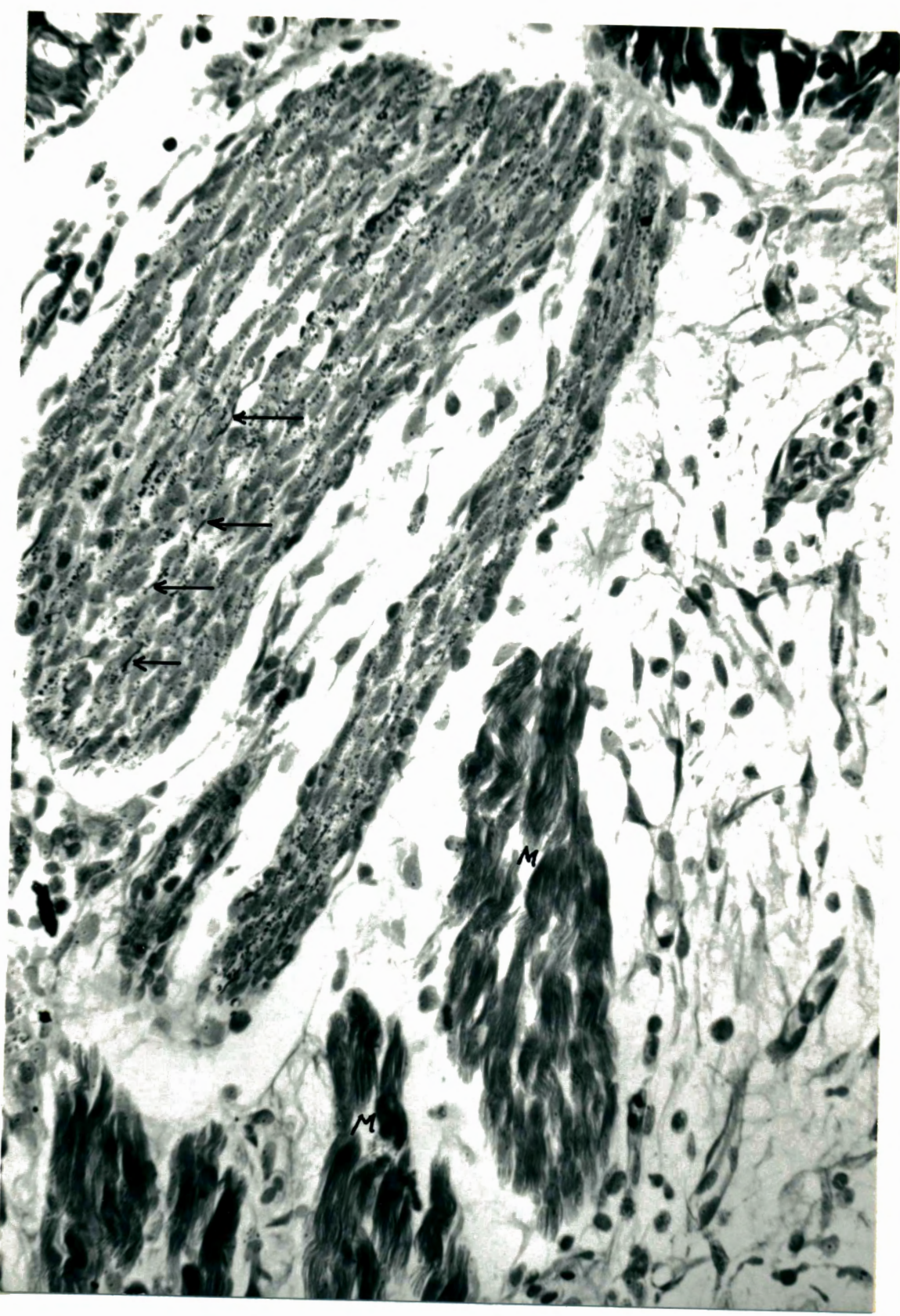

Figure 1. Denervated limb stained to show nerve fibers.

The animal (非14) was denervated $31 / 2$ days prior to fixation. Arrows indicate nerve fibers; the letter $M$ indicates muscle. 
design utilized a matrix in which animals can be grouped on a horizontal axis according to the age of the regenerate at injection and also be grouped on a vertical axis according to the interval between infection and fixation (see Table II and III). When we observe limbs from a group of animals injected at the same time, increases in the percent labeled cells in the first 24 hours following the final injection can be considered to represent an actual increase in uptake; whereas, the longer a limb is allowed to regenerate, the greater will be the probability that an increase in the percent labeled cells will be due to mitotic division occurring among the available population of previously labeled cells. Thus, when animals fixed at 24 hours after the final injection showed an increase in the uptake of tritiated thymidine over those fixed at 6 hours, it seems reasonable to assume sufficient tritiated thymidine was available to label cells during this period, because serum levels of isotope remain at a level nearly $10 \%$ of the post-injection peak levels during this period. Comparing animals fixed 48 and 72 hours after the final injection, any increase in the percentage of labeled cells should be due to a relative increase in the mitotic index for labeled cells relative to that of unlabeled cells, since little tritiated thymidine is available during this period. A particularly striking increase in mitotic index is apparent in the group of animals injected during the sixth day, see especially the increase in percent label between $53 / 4$ and $81 / 2$ days in group 4 animals as presented in Table III. In contrast with the above, we can consider groups of limbs fixed at the same time relative to their last injection but injected at different ages, the vertical axis of Table II. Thus, looking at progressively 
older regenerates fixed at 6 or 24 hours after their final injection, increases in the percent label reflect increased synthetic capacity in the limb stump at later stages of regeneration. As will be given in more detail below, both dedifferentiating stump and accumulating blastemal cells show increased synthetic activity in older regenerates.

An additional statistical analysis was considered desirable to determine the effect of denervation in each individual animal. The nonparametric Mann-Whitney $U$ was selected because the measurement used in this data is ordinal rather than interval scale, which makes a parametric test such as the $\underline{t}$ unsuitable. The Mann-Whitney $U$ is an alternative to the parametric $\underline{t}$ test and is superior because it avoids the assumptions inherent in the $t$ test. In addition it is eminently suitable to experiments in which a small number of samples are to be analyzed in the process of comparing a given pair of populations (Siegel, 1956). Thus, the Mann-Whitney $U$ provides a means for statistically determining the similarity or dissimilarity of labeling in the populations of cells from the pair of limbs of a given animal.

Sixteen animals were used to study DNA synthesis during the early dedifferentiative period and of these, four were injected with tritiated thymidine during the second day following denervation and amputation. They were allowed to continue regenerating for an additional period of time of up to 72 hours (see Table III, group 1). For these group 1 limbs an analysis of the percent labeled cells in eight tissue sections per limb for each limb pair representing a given animal indicates there is no slgnificant difference in the incorporation of tritiated thymidine in contralateral limbs $(p=.164$ to $p>.557)$, see Table III. The 
group 1 limbs, therefore, provide clear evidence for a lack of neural influence on DNA synthesis during the early period of cell dedifferentiation. Considering an additional nine animals of group 2, injected durIng the third day but otherwise treated identically to those above, the probability that the percent labeled cells is similar in contralateral limbs is variable $(p=.002$ to $p=.557)$. For one of the nine animals in group 2 the null hypothesis was rejected and the percent labeled cells were considered to be dissimilar; in addition, the difference between limbs in two of the animals was considered marginal; while the remaining 6 of 9 pairs of limbs were considered to be not significantly different $(p \geq .10)$. Part of the variation between the means of the percent labeled cells in this group is due to an increase in number of labeled cells related to the increase in the length of interval between injection and fixation. Another contributing factor to the divergence in percentage of labeled cells is variability among animals. As an example of group 2 results, animal $\# 14$ may be cited (see figures 1, 2 and 3). This animal was injected during the second day, and limbs were removed for study after $31 / 2$ days of regeneration, 24 hours after the last of 3 injections. It should be emphasized that the denervated limb of animal $\|_{14}$ contained virtually no nerves, see Figure 1, while the contralateral limb contained abundant nerves, see Figure 3. Figure 2, also illustrating animal $\#_{14}$, shows a level of label typical for group 2 limbs. Note that animal $\# 14$ is an example of a case where the denervated limb had a greater percent labeled cells than the innervated limb, but yet the difference between limbs was not statistically significant (see Table III). 


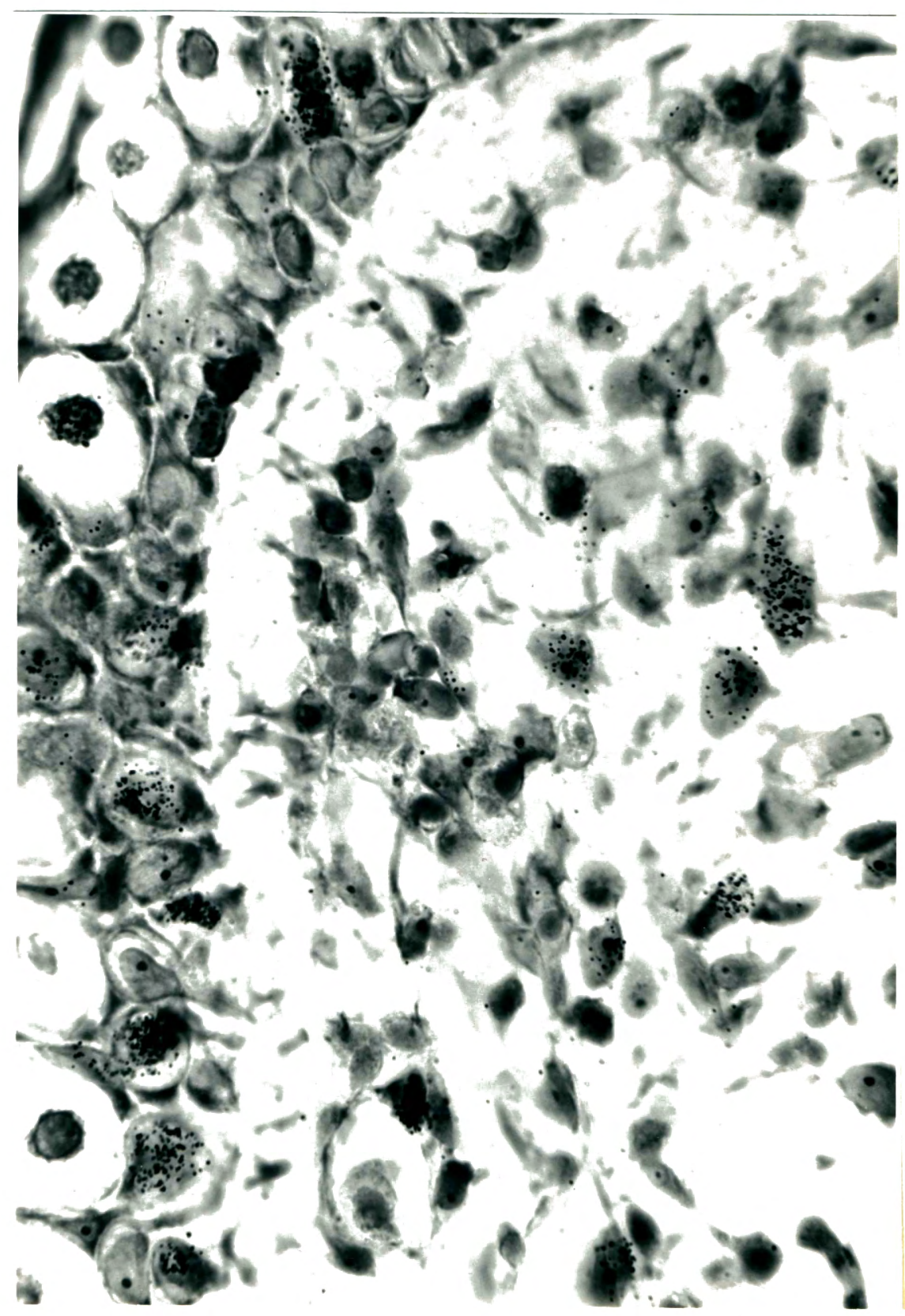

Figure 2. Silver grains over nuclei indicate tritiated thymidine labeling in the $31 / 2$ day regenerate.

Innervated and denervated regenerates of this age have an equivalent level of label. Innervated limb of animal \#14. X 475 


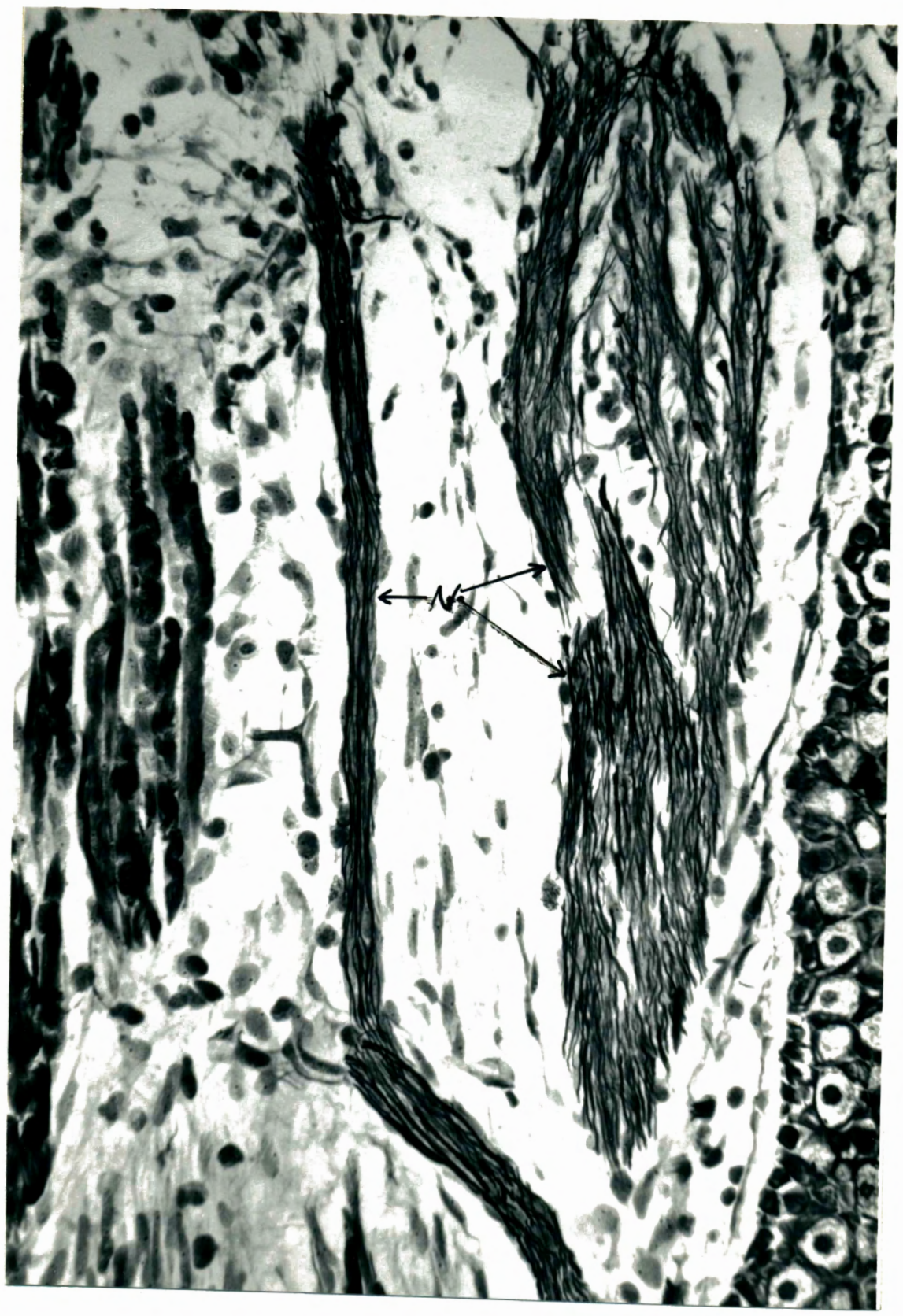

Figure 3. Normally innervated limb stained to show nerves (N). This is the contralateral limb to that shown in Figure 1 (Animal 14). 
Among the group 3 animals, injected on day 4 of regeneration, there was great variability among limbs fixed for study at 6,24 and 48 hours post-injection. Two of these animals provide examples which illustrate the disparity of response in this group. In animal $\#_{4}$ limbs were fixed at 48 hours post-injection, and the mean percent labeled cells indicated similarity in uptake of tritiated thymidine with a value of $20.66 \%$ in the innervated limb and a value of $22.30 \%$ for the denervated limb. By using the Mann-Whitney $U$ for a statistical analysis of all sixteen sections studied, the indication of similarity $(p>.520)$ was substantiated. An examination of all sections in the denervated limb demonstrated there were no nerves present. In contrast, animal 15 had Iimbs fixed at 6 hours post-injection, and a mean percent label of $22.66 \%$ was computed for the innervated limb whereas in the denervated limb the mean was $12.21 \%$. A Mann-Whitney $U$ test performed on the data from the 8 sections per limb in this animal establishes that the percent labeled cells in the contralateral limbs is dissimilar $(p=.001)$. Nerve staining indicated there was a very small nerve supply to the denervated limb; however, this small quantity was apparently insufficient to affect the regenerative processes in that limb. Consequently, two of the three animals in 3 group represent very divergent reactions to denervation. of the animals from group 3 discussed above, animal 非 15 had regenerated a total of $33 / 4$ days following denervation and amputation, whereas anfmal $\mathbb{N}_{4}$ was a $51 / 2$ day regenerate when fixed. It should be noted that for the denervated limb of animal 非 the humerus was not adequately trimmed and this was likely to have retarded the rate of regeneration, making it more comparable to a younger regenerate. 
In the animals from groups 2 and 3 discussed above, the reaction to denervation was variable. In some regenerates of $23 / 4$ to $51 / 2$ days, innervated and denervated limbs contained statistically similar percentages of labeled cells, even though the denervated limbs contained clearly sub-threshold numbers of nerves. In other cases, limbs were affected by denervation, i.e., the percentage of cells labeled was depressed in the denervated limbs. Thus, there is an apparent transition occurring from nerve independent to nerve-dependent DNA synthesis during this time period.

The absence of neural influence in the early period of dedifferentiation and the increasing variability of reaction to denervation with time, created the concern that some animals were not adequately denervated. After successfully restaining sections originally stained with Azure B by using Samuel's nerve stain technique (1953), observation of all tissue sections for each denervated limb indicated the concern was need1ess. The nervous tissue remaining in denervated limbs was of small quantity and usually consisted of a few fibers remaining in a degenerating nerve as in Figure 1.

The fourth group consisted of three animals injected on the sixth day following denervation and amputation, with limbs allowed to continue regeneration for an additional 6,24 or 72 hours. In each of these animals the means of the percent labeled cells were significantly different when contralateral limbs were compared (see Table III). The mean in the innervated 1imb in case $\equiv_{17}$ was slightly lower than expected, which could have been due in part to individual animal variability; however, it is also possible some of the tritiated thymidine 
was expressed back out through the route of injection following withdrawal of the needle and thus was unavailable for incorporation. In each of these three cases the null hypothesis that the percent labeled cells in contralateral limbs was similar, and thus that DNA synthesis was similar, was rejected at an extremely high level of significance ( $p<$ .001). See Figures 4 and 5 for an illustration of the differing levels of uptake in contralateral limbs of this group.

It might be possible that the percent labeled cells in the entire limb tip is not a true measure of DNA synthesis in the case of older regenerates. In regenerates of more than 5 days, mesenchymatous cells are accumulating in the tip of the innervated but not the denervated limb, and these accumulating cells would be included in the computation of percent labeled cells, thereby possibly distorting the data. In view of this, the following hypothesis was tested: if the nerve has no effect on DNA synthesis, the percent labeled cells in the dedifferentiating stump tissue should be equal in both innervated and denervated limbs. Consequently, additional counts were done of proximal, nonmesenchymatous cells for animals regenerating $53 / 4$ and $61 / 2$ days. The percent labeled cells for individual sections as well as the means for these limbs were determined for both pairs of contralateral limbs and a statistical analysis comparing innervated to denervated limbs was performed using the Mann-Whitney U. The values for percent labeled cells in proximal tissues for both ages showed a significant difference ( $\mathrm{p}=$ .002) between innervated and denervated limbs. Therefore, DNA synthesis appears to be generally influenced by the nerve during this later portion of the dedifferentiative phase represented by group 4 . 


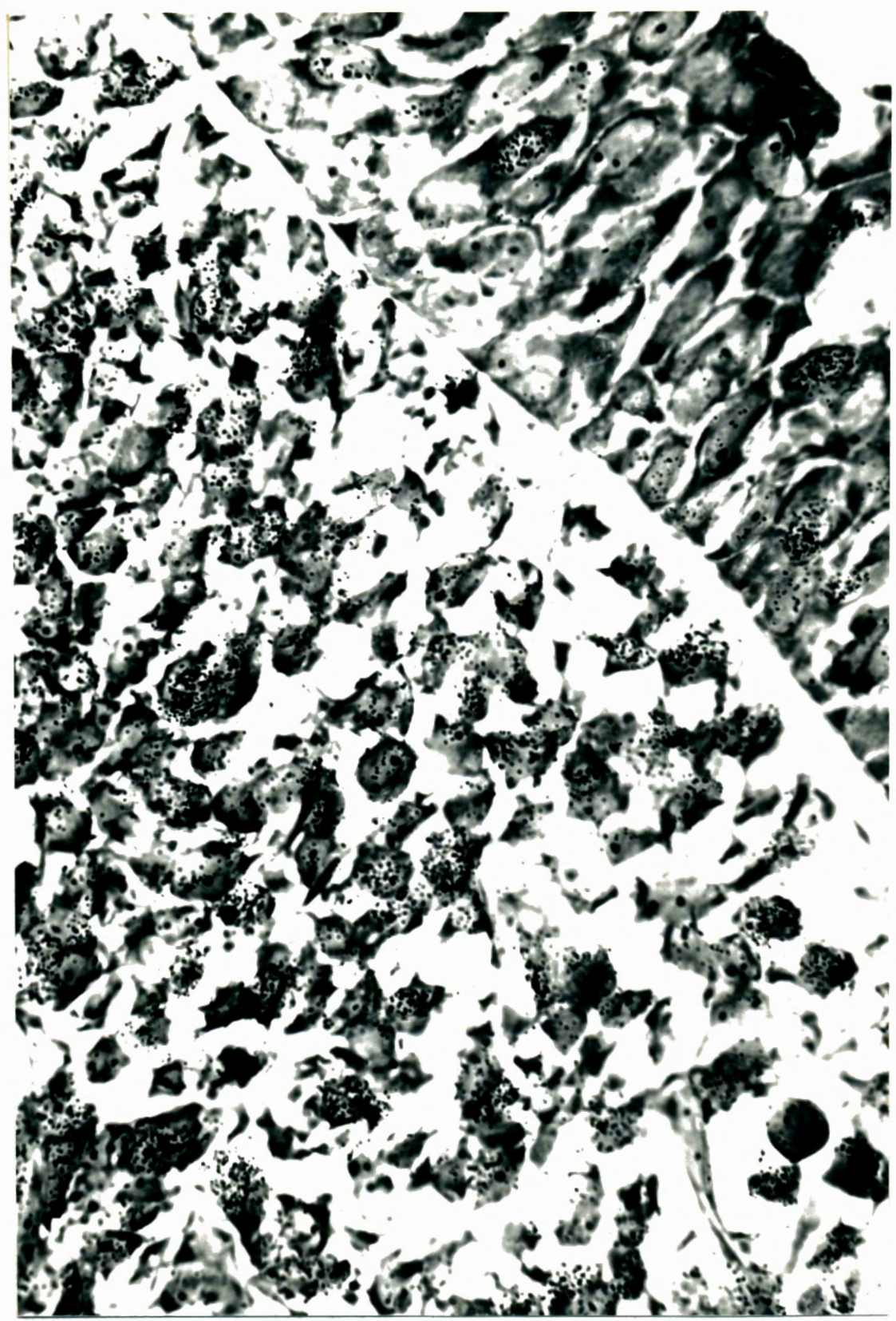

Figure 4. Silver grains over nuclei indicate the high level of labeling by tritiated thymidine in the innervated limb of a regenerate late in the dedifferentiative phase of limb regeneration. (Animal 非19, $81 / 2$ day regenerate, innervated) 


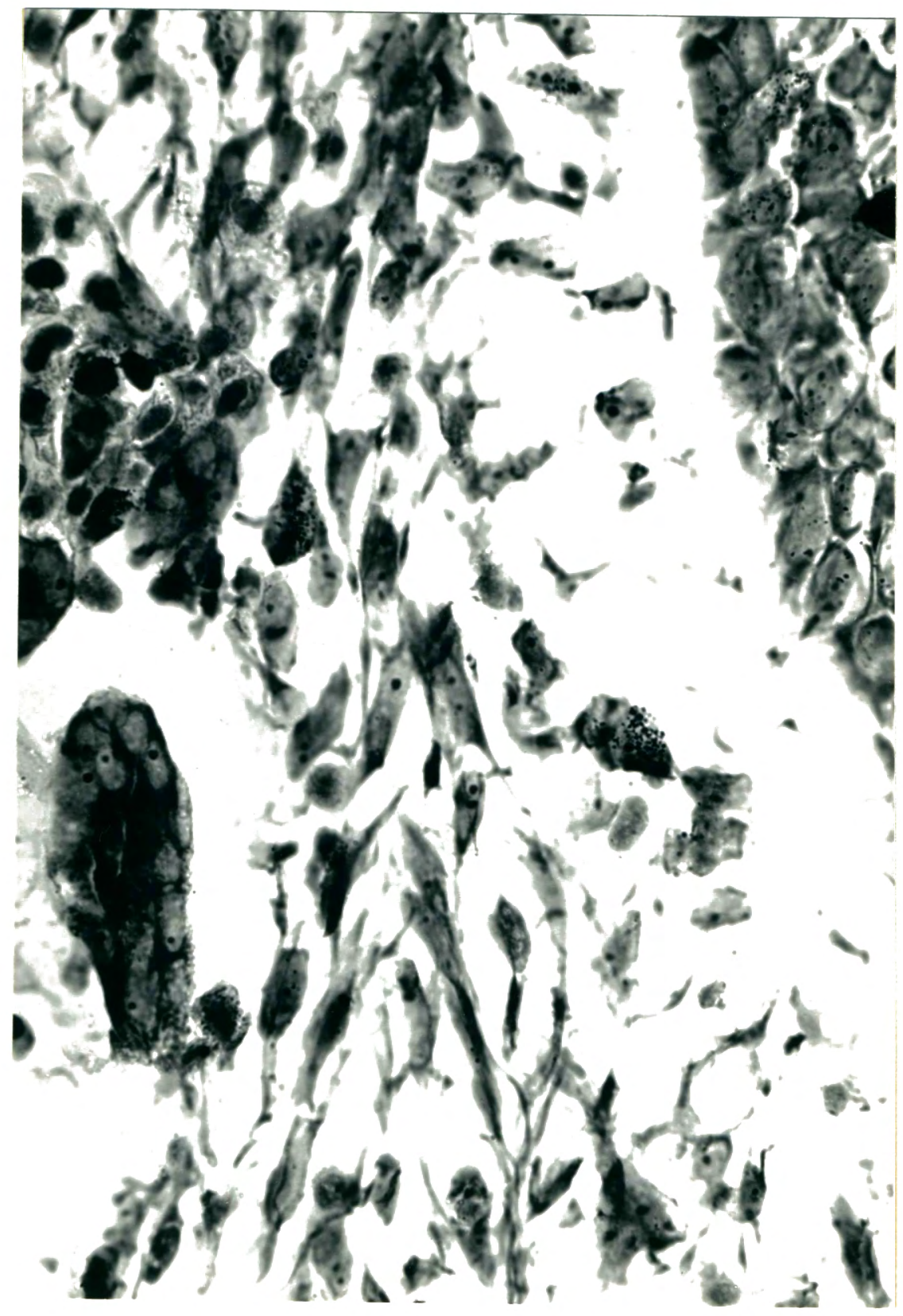

Figure 5. Silver grains over nuclei indicate the low level of labeling in the denervated limb of a regenerate late in the dedifferentiative phase of limb regeneration. (Animal 非19, 8 1/2 day regenerate, denervated). 
Denervation not only alters cellular capacity to synthesize DNA, but it may also affect mitosis, depending on the age of the regenerate. A comparison of the mitotic index in denervated and innervated limbs of regenerates of less than 5 days shows no significant difference; whereas, in the three cases allowed to regenerate more than $53 / 4$ days a significant difference is noted. Thus, one of the likely effects of denervation is a depression of the mitotic index in the denervated limb of regenerates of approximately 6 days or more (see Figure 6). Similar results have been reported by Kelly and Tassava (1973) as well as Sperry (1971). In addition to the basically quantitiative feature of uptake, it is important to note and take advantage of the spatial and morphological potential of the radioautographic technique used in this study. With this technique it is possible to determine the involvement of epidermis, muscle and connective tissue (soft tissues), as well as cartilage in the dedifferentiative processes. Muscle and connective tissue are the first of the internal stump tissues to show an uptake of tritiated thymidine; at $13 / 4$ days there are labeled cells in the soft tissues of the stump. In contrast, incorporation of tritiated thymidine in cartilage does not occur until later. Regenerates injected during day 3 and fixed 6 hours subsequent to that time contain scattered labelled cartilage cells indicating that the DNA synthesis associated with dedifferentiation is finally beginning to occur in this tissue. In the epidermal cap or the epidermis covering the distal portion of the limb tip, scattered labeled cells are visible in all limbs from this study. This observation is in agreement with Hearson's (1966) finding that tritiated thymidine directly labels cells at a variety of locations in the distal portion of the epidermis in the axolotl. 


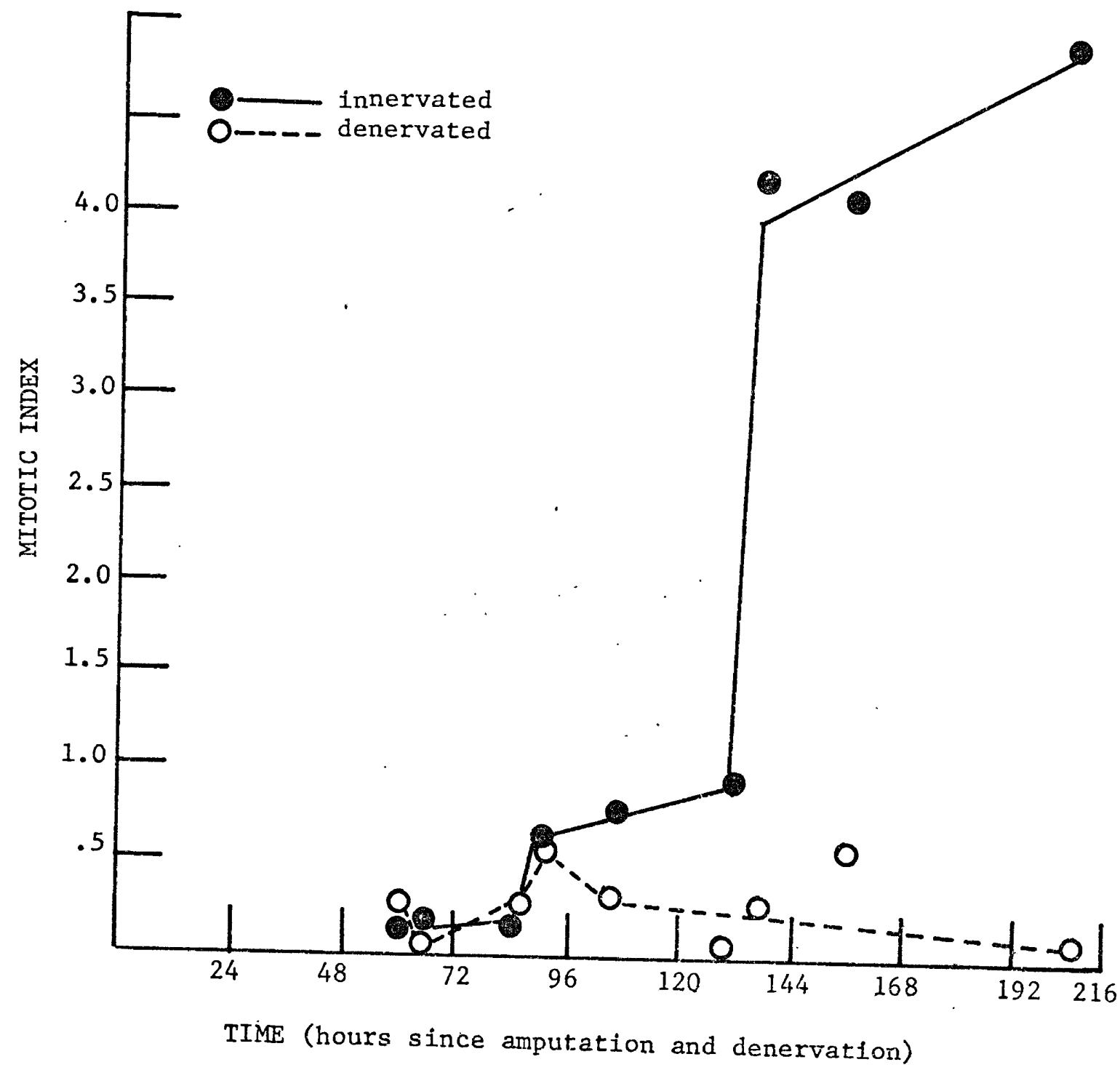

Figure 6. Graphic illustration of Mitotic Index for both innervated and denervated limbs duxing the dedifferentiative phase of regeneration. 


\section{DISCUSSION}

The dedifferentiative phase of regeneration in the innervated limb may, for convenience be divided into two parts; during the early portion, dedifferentiation and DNA synthesis begin and the mitotic index remains low; whereas in the later portion, dedifferentiation and DNA synthesis continue but the mitotic index increases in the forming blastema. Radioautographic data from limbs of animals injected with tritiated thymidine at various times during the dedifferentiative phase of limb regeneration indicates that time is an extremely important factor when the effects of denervation are studied. Time is also an important parameter in an investigation of the effect of denervation on mitosis.

DNA synthesis precedes mitosis in the cell cycle, and it has been demonstrated that synthesis must be complete before a cell is competent to enter the mitotic phase of the cycle (Hartwel1, Culotti, Pringle and Reid, 1974). Consequently the low mitotic index found concomitantly with depressed DNA synthesis in denervated limbs could be attributed to cause and effect. That is, if a cell is incapable of synthesizing DNA, then the cell cycle is interrupted and mitosis cannot occur. Thus, the low mitotic index observed in this study would be expected during the late portion of the dedifferentiative phase of limb regeneration in a denervated limb.

Basing their hypothesis on observations of mitotic activity only, Kelly and Tassava (1973) have postulated that DNA synthesis in the early denervated limb would be depressed. However, in the present study, the early group of limbs injected during the second day of regeneration shows that absence of nerve tissue has little or no effect on the ability of 
stump cells to synthesize DNA. Synthesis is occurring at significant levels in both muscle and connective tissue during this early period, thus laying the foundation for future mitotic activity. This early DNA synthesis also reflects on their suggestion that regeneration is not initiated in the denervated limb because the nerve is necessary for the normal early increase in mitotic activity (Kelly and Tassava, 1973). Since this study shows that DNA synthesis and thus the potential for mitosis is equal in denervated and innervated limbs, it appears that regeneration may be initiated in a normal manner in the denervated limb at least with regard to the internal stump tissues. Thus, we should consider the epidermal cap in our explanation of the failure of denervated limbs to regenerate (see below).

Limbs labeled on days 3 and 4 show a variable reaction to denervation. During this transition period, most of the limbs are unaffected by denervation, whereas in a few DNA synthesis is depressed in the denervated limb, indicating a transition from nerve independent to nerve-dependent DNA synthesis. This dissimilarity in DNA synthesis when comparing innervated and denervated limbs would indicate that DNA synthesis is depressed by denervation and therefore, as synthesis precedes mitosis, the decrease in mitotic activity observed in this study would be anticipated. Similar findings of decreased mitotic activity in denervated limbs of regnerates of more than 5 days are reported by Sperry (1971) as well as by Kelly and Tassava (1973).

The work of Dresden (1969) on older regenerates also indicates DNA synthesis is nerve dependent. Dresden used biochemical methods to demonstrate that denervation depresses synthesis at the palette stage 
of regeneration in the adult newt. In the palette stage there is a vast population of cells available to take part in synthetic activity. Using biochemical methods it is possible to determine that synthesis is occurring to a lesser degree in denervated than innervated limbs, but it is not possible to determine whether this disparity is due to a decreased rate of synthesis in each cell or whether fewer cells are participating. The present study extends our knowledge of events occurring in the denervated limb. It has been passible to establish not only that there are fewer cells demonstrating a synthetic capacity, but that the cells undergoing synthesis are primarily dedifferentiating cells in the proximal stump tissues, at least during the late dedifferentiative phase of regeneration in the axolotl. It should be noted that Dresden's work and this study differ in the species of salamander used, the age of the animal, and the phase of regeneration. While each of these factors has an influence, the reaction to denervation at the cellular level should be comparable. Nerve dependent DNA synthesis during this later stage was further substantiated by this study's observations indicting a significant difference in DNA synthesis between innervated and denervated limbs when proximal tissue is examined.

It seems, therefore, since DNA synthesis is similar in innervated and denervated limbs up to about the fourth day of dedifferentiation, there should be a population of cells available that have gone through synthesis and which could continue through $G_{2}$ and into the mitotic phase of the cell cycle. This population of cells apparently is available in the innervated limb as indicated by the accumulation of mesenchymatous cells beneath the epidermal cap (see Figure 7). However, in 


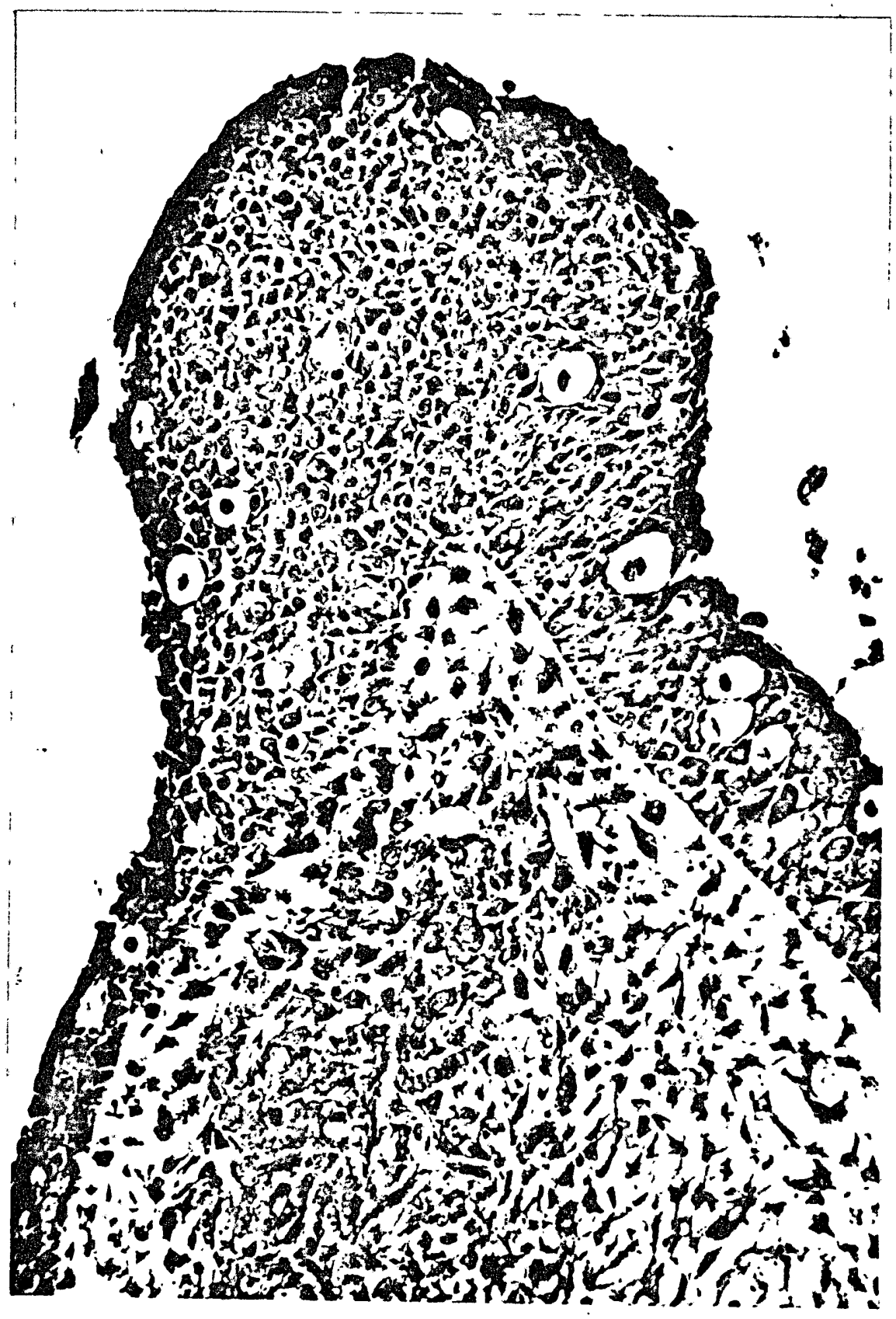

Figure 7. This photomicrograph of an $81 / 2$ day regenerate illustrates the accumulation of cells beneath the epidermal cap. (Animal \#19) 
the denervated limb this does not seem to be the case (see Figure 8). Animals injected with tritiated thymidine on the fourth day show that DNA synthesis is occurring, and the presence of dissociated cells indicates dedifferentiation is also progressing. However, in a 6 day denervated regenerate tissue sections of the limb stump do not show the presence of these dedifferentiated mesenchymatous cells, even though by this much later stage such cells should be evident. Thus, there is no accumulation of mesenchymatous cells beneath an epidermal cap in denervated limbs.

The epidermal cap is a prominent feature of the dedifferentiative phase and is critical for the aggregation of the dedifferentiated cells from the stump tissue at the tip of the limb (see Figure 7). An epidermal cap does not usually form on a denervated limb (Thornton, 1954; 1956; 1968; Singer, 1959), and it has been demonstrated that the presence of the epidermal cap is a.prerequisite to the aggregation of cells for blastemal formation (Thornton, 1954, 1956, 1957). Furthermore, using the technique of a deviated epidermal cap, Thornton and Steen (Thornton, 1960; Thornton and Steen, 1962; Steen and Thornton, 1963) demonstrated a clear cap influence on the amassing of the mesenchymal cells. A variety of influences on cell accumulation at the limb tip have been considered. In the innervated limb, nerves from the proximal tissue pass through the dedifferentiating portion of the stump and are seen to continue into the epidermal cap (Thornton, 1954). It has been postulated, therefore, that the nerves could be providing a substratum on which the mesenchymatous cells could travel and would this tend to accumulate beneath the cap (Singer, 1959; Thornton, 1960). However, as some of the experiments 


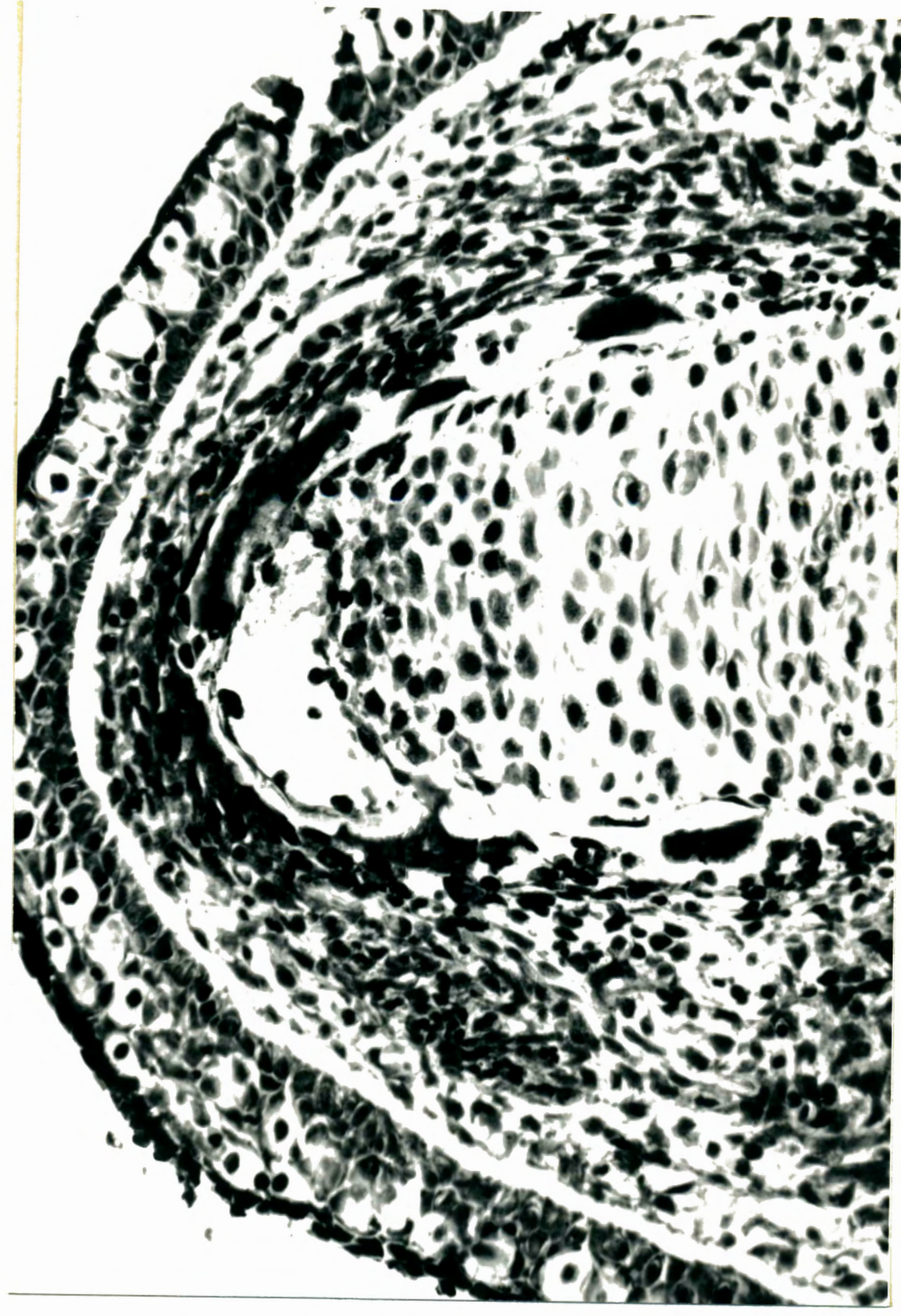

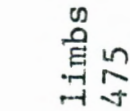

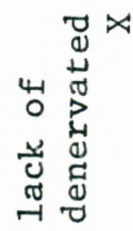

过告

of

崩

is ?

可

검

न्त

悬营

is $4-1$

苗哭

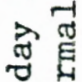

$+\sqrt{-4}$

ले न्न

in 4

प 0

$+$

跣

(1)

㟧

(1) वृ

4. है

둉

때

$4 \pi-$

on 00 구

44

c)

面

퍼

잉

क. ए ए

年葛

- 0

مأ-

点 
involving the deviation of the epidermal cap utilized aneurogenic animals (Thornton and Steen, 1962; Steen and Thornton, 1963) contact guidance of mesenchymatous cells by nerve fibers seems unlikely. It seems more tenable to assume that a chemical interaction occurs between the nerve and the surrounding tissue (Singer, 1952; Singer and Salpeter, 1961) and that, perhaps, a postulated 'trophic factor' (Singer, 1952, 1959; Singer and Mutterper1, 1962; Thornton and Thornton, 1965; Schmidt, 1962; Thornton, 1970) from the nerve influences the formation of the epidermal cap. Therefore, the main thrust of the influence of the nerve during the early portion of the dedifferentiative phase of limb regeneration could be an influence on the epidermis and not on the internal stump tissues. Observations of the epidermal area in the course of this study, along with evidence presented by Hearson (1966) collectively suggest that the nerve influence on the cap is not exerted via DNA synthesis or mitosis itself.

Finally, in contrast, animals allowed to regenerate more than five days before labeling show a definite dissimilarity between innervated and denervated limbs with respect to ability to synthesize DNA in cells of the whole limb tip. During the later portion of the dedifferentiative phase, that is from approximately the 6th to the 10th day of regeneration, it appears the nerve has a profound effect on cellular capacity to synthesize DNA. Thus, during this later portion of the dedifferentiative phase, DNA synthesis is apparently nerve-dependent. Since interference with DNA synthesis, as observed in this work, precludes continuation of the cell cycle, an additional effect of denervation is a depressed mitotic index in the denervated 1imb. This conclusion, derived 
from the present study, is in agreement with the findings of earlier workers in which they found the mitotic index in innervated and denervated limbs to be similar up to about the 5th day (Kelly and Tassava, 1973) and exceedingly dissimilar between the 6 th and 10th days (Sperry, 1971). Thus, the present work extends our knowledge of the effect of the nerve on the conjoined roles of DNA synthesis and mitosis during the dedifferentiative period of limb regeneration.

In summation, it appears that the primary influence of the nerve during the first 4 days of limb regeneration is on epidermal cap formation. Beginning on approximately the 4 th day the nerve influence shifts from the epidermis to the internal stump tissues as there is an increasing level of dependence of DNA synthesis on the nerve influence. During the remainder of the dedifferentiative phase DNA synthesis is highly nerve dependent and is therefore substantially depressed in the denervated limb. Since the nerve has been observed to exert definite influence on DNA synthesis during the cell cycle in regenerates late in the dedifferentiative phase, this study. documents a basis for the neural influence on mitotic activity that has been observed by other workers studying Iimb regeneration. 
Butler, Elmer G., and Oscar E. Schotte. 1949. Effects of Delayed Denervation on Regenerative Activity in Limbs of Urodele Larvae. Journal of Experimental Zoology, 112:361-392.

Caro, Lucien G. 1964. High-Resolution Autoradiography. In: Methods in Cell Physiology. D. M. Prescott, ed. Academic Press, New York, Vo1. 1:327-363.

Dresden, Marc. H. 1969. Denervation Effects on Newt Limb Regeneration: DNA, RNA, and Protein Synthesis. Developmental Biology, 19:311-320.

Flax, M. H., and M. H. Himes. 1952. Microspectrophotometric Analysis of Metachromatic Staining of Nucleic Acids. Physiological Zoology, 25:297-311.

Hartwe11, Leland H., Joseph Culotti, John R. Pringle and Brian J. Reid. 1974. Genetic Control of the Cell Division Cycle in Yeast. Sclence, 183:46-51.

Hay, Elizabeth D. and Donald A. Fischman. 1961. Origin of the Blastema in Regenerating Limbs of the Newt Triturus viridescens Developmental Biology, 3:26-59.

Hearson, Lester L. 1966. An Analysis of Apical Proliferation in the Forelimb Regeneration Blastema of the Axolot 1 Ambystoma mexicanum. Ph.D. Thesis, Michigan State University.

Kelly, Daryl J. and Roy A. Tassava. 1973. Cell Division and Ribonucleic acid Synthesis during the Initiation of Limb Regeneration in Larval Axolotls (Ambystoma mexicanum) Journal of Experimental Zoology, 185:45-54.

Samuel, E. P. 1953. Towards Controlable Silver Staining. Anatomical Record, 116:511-519.

Schotte, Oscar E. and Elmer G. Butler. 1941. Morphological Effects of Denervation and Amputation of Limbs in Urodele Larvae. Journal of Experimental Zoology, 87:279-321.

Schotte, Oscar E., Elmer G. Butler and Robert T. Hood. 1941. Effects of Transplanted Blastemas on Amputated Nerveless Limbs of Urodele Larvae. Proceeding of the Society for Experimental Biology and Medicine, 48:500-503.

Siegel, Sidney. 1956. Non-Parametric Statistics for the Behavioral Sclences. McGraw-Hil1, New York.

Singer, Marcus. 1952. The Influence of the Nerve in Regeneration of the Amphibian Extremity. Quarterly Review of Biology, 27:169-200. 
Singer, Marcus. 1959. The Influence of Nerves on Regeneration. In: Regeneration in Vertebrates. C. S. Thornton, ed. PP. 59-80. University of Chicago Press, Chicago, Illinois.

Singer, Marcus. 1965. A Theory of the Trophic Nervous Control of Amphibian Limb Regeneration, Including a Re-Evaluation of Quantitative Nerve Requirements. In: Regeneration in Animals and Related Problems. V. Kiortsis, ed. North-Holland Publishing Company, Ams terdam. pp. 20-32.

Singer, Marcus and E1len Mutterper1. 1963. Nerve Fiber Requirements for Regeneration in Forelimb Transplants of the Newt Triturus. Developmental Biology, 7:180-191.

Singer, Marcus and Miriam M. Salpeter. 1961. Regeneration in Vertebrates: The Role of the Wound Epithelium. In: Growth in Living Systems. M. X. Zarrow, ed. Basic Books, Inc. New York. pp. 277-311.

Sperry, Donna Gail. 1971. The Effect of Denervation on Nucleic Acid Synthesis and Mitotic Activity in Nerve Dependent and NerveIndependent Blastemas of the Axolot1, Ambystoma mexicanum. Masters Thesis, The Ohio State University.

Steen, Trygve P. 1968. Stability of Chondrocyte Differentiation and Contribution of Muscle to Cartilage during Limb Regeneration in the Axolotl (Siredon mexicanum). Journal of Experimental Zoology. 167:49-78.

Steen, Trygve P. and Charles S. Thornton. 1963. Tissue Interaction in Amputated Aneurogenic Limbs of Ambystoma Larvae. Journal of Experimental Zoology, 154:207-222.

Thornton, Charles S. 1954. The Relation of Epidermal Innervation to Limb Regeneration in Ambystoma Larvae. The Journal of Experimental Zoology, 127:5 $\overline{77-596 .}$

Thornton, Charles S. 1956. The Relation of Epidermal Innervation to the Regeneration of Limb Deplants in Amblystoma Larvae. Journal of Experimental Zoology, 133:281-300.

Thornton, Charles S. 1957. The Effect of Apical Cap Removal on Limb Regeneration in Amblystoma Larvae. Journal of Experimental Zoology, 134:357-382.

Thornton, Charles S. 1960. Influence of an Eccentric Epidermal Cap on Limb Regeneration in Amblystoma Larvae. Developmental B1ology, 2:551-569. 
Thornton, Charles S. 1965. Influence of the Wound Skin on Blastemal Cell Aggregation. In: Regeneration in Animals and Related Problems. V. Kiortsis, ed. North-Holland Publishing Company, Amsterdam. pp. 333-340.

Thornton, Charles S. 1968. Amphibian Limb Regeneration. In: Advances in Morphogenesis. M. Abercrombie, J. Brachet and T. H. King, eds. Academic Press, New York and London. pp. 205-249.

Thornton, Charles S. 1970. Amphibian Limb Regeneration and its Relation to Nerves. American Zoologist, 10:113-118.

Thornton, Charles S. and Mary T. Thornton. 1965. Recuperation of Regeneration in Denervated Limbs of Ambystoma Larvae. Journal of Experimental Zoology, 173:293-302.

Thornton, Charles S. and Trygve P. Steen. 1962. Eccentric Blastema Formation in Aneurogenic Limbs in Ambystoma Larvae Following Epidermal Cap Deviation. Developmental Biology, 5:328-343. 